\title{
Rhizobium gallicum sp. nov. and Rhizobium giardinii sp. nov., from Phaseolus vulgaris Nodules
}

\author{
NOËLLE AMARGER,* VALÉRIE MACHERET, AND GISÈLE LAGUERRE \\ Laboratoire de Microbiologie des Sols, Centre de Microbiologie du Sol et de \\ l'Environnement, INRA, 21034 Dijon Cedex, France
}

\begin{abstract}
Thirty-one strains of two new genomic species (genomic species 1 and 2) of rhizobia isolated from root nodules of Phaseolus vulgaris and originating from various locations in France were compared with reference strains of rhizobia by performing a numerical analysis of 64 phenotypic features. Each genomic species formed a distinct phenon and was separated from the other rhizobial species. A comparison of the complete 16S rRNA gene sequences of a representative of genomic species 1 (strain $R 602 \mathrm{sp}^{\mathrm{T}}$ ) and a representative of genomic species 2 (strain $\mathrm{H152}^{\mathrm{T}}$ ) with the sequences of other rhizobia and related bacteria revealed that each genomic species formed a lineage independent of the lineages formed by the previously recognized species of rhizobia. Genomic species 1 clustered with the species that include the bean-nodulating rhizobia, Rhizobium leguminosarum, Rhizobium etli, and Rhizobium tropici, and branched with unclassified rhizobial strain OK50, which was isolated from root nodules of Pterocarpus klemmei in Japan. Genomic species 2 was distantly related to all other Rhizobium species and related taxa, and the most closely related organisms were Rhizobium galegae and several Agrobacterium species. On the basis of the results of phenotypic and phylogenetic analyses and genotypic data previously published and reviewed in this paper, two new species of the genus Rhizobium, Rhizobium gallicum and Rhizobium giardinii, are proposed for genomic species 1 and 2, respectively. Each species could be divided in two subgroups on the basis of symbiotic characteristics, as shown by phenotypic (host range and nitrogen fixation effectiveness) and genotypic data. For each species, one subgroup had the same symbiotic characteristics as $R$. leguminosarum biovar phaseoli and $R$. etli biovar phaseoli. The other subgroup had a species-specific symbiotic phenotype and genotype. Therefore, we propose that each species should be subdivided into two biovars, as follows: $R$. gallicum biovar gallicum and $\boldsymbol{R}$. gallicum biovar phaseoli; and $R$. giardinii biovar giardinii and $R$. giardinii biovar phaseoli.
\end{abstract}

Until recently, the rhizobia that nodulate the roots of common bean, Phaseolus vulgaris, were classified in a single species, Rhizobium leguminosarum (23). This species was subdivided into three biovars differentiated by legume host specificity, and strains recovered from Phaseolus spp. nodules were assigned to $R$. leguminosarum bv. phaseoli. Although this biovar has long been recognized as a very heterogeneous group on the basis of a variety of phenotypic $(5,16,40,41)$ and genotypic $(7,15,21$, 38) criteria, it is only with the development of the molecular approach that it gave rise to new taxa. First, based on host range characteristics encoded by genes located on the symbiotic plasmid and on the organization of the symbiotic plasmid $(33,35)$, two subgroups were distinguished within $R$. leguminosarum bv. phaseoli. Type I strains had multiple copies of the nitrogenase reductase gene, nifH (39), and a narrow host range (6) (which recently appeared to be less restricted than first thought [18]), whereas type II strains had a single copy of nifH and a broader host range $(6,34)$. Later, the unusually high level of genetic diversity among Mexican and South American isolates (38) revealed by multilocus enzyme electrophoresis (MLEE) suggested that several species could be delineated among the isolates assigned to $R$. leguminosarum bv. phaseoli and thus brought into question the meaning of this taxonomic unit. The type II strains included in the study formed one of the lineages. A larger sample of type II strains was analyzed further and was classified by MLEE and numerical taxonomy (36). Genotypic characterization of representative strains by

\footnotetext{
* Corresponding author. Mailing address: Laboratoire de Microbiologie des Sols, CMSE, INRA, 17, rue Sully, B.V. 1540, 21034 Dijon Cedex, France. Phone: 3338063 30 92. Fax: 333806332 24. E-mail: amarger@dijon.inra.fr.
}

partial sequencing of the 16S rRNA gene, DNA-DNA hybridization, and ribosomal DNA (rDNA) organization led to the creation of a new species of the genus Rhizobium, Rhizobium tropici, corresponding to the former type II (36). Two subgroups, subgroups IIA and IIB, were described in this species to accommodate the relatively low level of DNA-DNA homology $(36 \%)$ and differences in phenotypic and genotypic characteristics, differences which were recently emphasized by the observation of a specific megaplasmid in each group (13). Primarily on the basis of differences in a 260-bp nucleotide sequence of the $16 \mathrm{~S}$ rRNA, type I strains and nonsymbiotic isolates of American origin were later reclassified as Rhizobium etli sp. nov. (44). However, the distribution of the $R$. etli $16 \mathrm{~S}$ rRNA allele is not limited to the Americas, and so far this allele has also been identified in France and Spain (1) and in Indonesia and Africa (49). On the other hand, Eardly et al. (11) have detected the $R$. leguminosarum 16S rRNA allele in isolates from South America. When analyzed by MLEE, the isolates harboring this allele were found to be more closely related to lineages of strains harboring the $R$. etli allele than to each other. It was hypothesized that the $R$. leguminosarum allele had been horizontally transferred and recombined among distantly related chromosomal lineages. This implies that the boundaries between $R$. leguminosarum and $R$. etli are rather loose. The level of DNA-DNA relatedness $(45 \%)$ and the homology of chromosomal regions, such as the lac and lipopolysaccharide gene regions, observed for the two species (26) suggest that other DNA transfers and recombinations between these species might have occurred. Moreover, the symbiotic plasmid genes of the two species are homologous and are organized similarly $(8,52)$. It has been assumed that $R$. leguminosarum bv. phaseoli might have arisen through horizontal transfer of the symbiotic plasmid from $R$. etli to $R$. 
leguminosarum (44). Whatever their origin, these two species are more closely related to each other than the two subgroups of $R$. tropici are. Phylogenetically, an analysis of the whole sequence of the 16S rRNA genes indicated that $R$. etli, $R$. leguminosarum, and $R$. tropici formed a coherent monophyletic group which also included an independent lineage containing a single isolate from bean nodules $(50)$ and the nonrhizobial species Agrobacterium rhizogenes, which is closely related to $R$. tropici (54). However, these three species do not account for all of the genotypic diversity of bean-nodulating rhizobia $(14,38$, $50)$.

Some years ago, in a study of the diversity of field isolates of R. leguminosarum at a single site in France, Laguerre et al. (28) detected among bean nodule isolates a group of strains whose genotype differed from that of $R$. leguminosarum. Strains belonging to this group were also detected in another field 300 $\mathrm{km}$ away and among a collection of strains isolated from various sites in France (14). In this collection, a second novel group of six strains which could not be assigned to any of the three species or to the first group was also identified. The two groups, which had been differentiated from $R$. leguminosarum, $R$. etli, and $R$. tropici mainly by a restriction fragment length polymorphism analysis of total DNA performed with several DNA probes $(14,28)$, were later assigned to two new genomic species on the basis of the results of DNA-DNA hybridization and a partial $16 \mathrm{~S}$ rRNA gene sequence analysis (27). Phylogenetically, the closest relative of genomic species 1 was $R$. etli, and the organisms most closely related to genomic species 2 were Rhizobium galegae (30) and Rhizobium loti (22). At that time, these new species were not named since additional data on their phenotypic characteristics were required according to the criteria outlined by Graham et al. (17) for the description of new species of the genus Rhizobium.

In the present study, phenotypic features of 90 strains isolated from Phaseolus spp. nodules and previously assigned to one of the two genomic species or to one of the three previously named species of rhizobia that nodulate beans were compared to the phenotypic features of reference rhizobial strains by numerical taxonomy. The phylogenetic position of each of the genomic species within the $\alpha-2$ subgroup of the class Proteobacteria was assessed by determining the nucleotide sequence of the whole $16 \mathrm{~S}$ rRNA gene of one representative strain. As a result of the present and previous studies, we propose two new species, Rhizobium gallicum and Rhizobium giardinii.

\section{MATERIALS AND METHODS}

Bacterial strains. A total of 112 strains were used in this investigation (Table 1). Eighty-nine strains were from our collection and had been isolated from root nodules of field-grown Phaseolus vulgaris sampled in various regions of France (14), in two fields in Java (Indonesia), and in one field in Burundi (49). The other 23 strains were type or representative strains of Rhizobium and Sinorhizobium species. All strains were maintained on agar slopes of Bergersen's medium (3) supplemented with $0.2 \mathrm{~g}$ of yeast extract per liter. Since isolation they had been stored at $-80^{\circ} \mathrm{C}$ on the same medium containing $20 \%$ (vol/vol) glycerol

Phenotypic characteristics. The following features were analyzed: (i) utilization of L-arabinose, D-fructose, D-galactose, D-glucose, D-glucosamine, D-glucuronate, lactose, maltose, mannitol, D-mannose, raffinose, L-rhamnose, D-ribose, D-sorbitol, sorbose, trehalose, xylose, dulcitol, erythritol, glucitol, inositol, glycerol, mannopine, octopine, soluble starch, citrate, oxalate, tartrate, lactate, and gluconate as sole carbon sources; (ii) utilization of L-arginine, L-alanine, Lasparagine, L-aspartate, L-cysteine, L-cystine, L-glutamine, L-glutamate, glycine, L-histidine, L-proline, L-isoleucine, L-leucine, L-lysine, L-methionine, L-phenylalanine, L-proline, L-serine, L-threonine, L-tryptophan, L-tyrosine, and L-valine as sole nitrogen sources; (iii) tolerance to nalidixic acid $(40 \mu \mathrm{g} / \mathrm{ml})$, streptomycin (3 $\mu \mathrm{g} / \mathrm{ml})$, spectinomycin $(5 \mu \mathrm{g} / \mathrm{ml})$, and kanamycin $(10 \mu \mathrm{g} / \mathrm{ml})$ added to TY medium (4); (iv) growth on TY medium containing $0.5,1$, and $2 \% \mathrm{NaCl}$; (v) growth on TY medium at $\mathrm{pH} \mathrm{4,5}$, and 8.5 ; (vi) growth on TY medium lacking calcium; and (vii) growth on Luria-Bertani medium.

To test for substrate utilization, the different carbon sources were added at a final concentration of $1 \mathrm{~g} /$ liter to a basal medium containing (per liter) $1 \mathrm{~g}$ of $\mathrm{K}_{2} \mathrm{HPO}_{4}, 1 \mathrm{~g}$ of $\mathrm{KH}_{2} \mathrm{PO}_{4}, 0.01 \mathrm{~g}$ of $\mathrm{FeCl}_{3} \cdot 6 \mathrm{H}_{2} \mathrm{O}, 0.2 \mathrm{~g}$ of $\mathrm{MgSO}_{4} \cdot 7 \mathrm{H}_{2} \mathrm{O}, 0.1 \mathrm{~g}$ of $\mathrm{CaCl}_{2}, 1 \mathrm{~g}$ of $\left(\mathrm{NH}_{4}\right)_{2} \mathrm{SO}_{4}$, and $15 \mathrm{~g}$ of agar. When substrates were tested as nitrogen sources, they were added at a concentration of $0.5 \mathrm{~g} /$ liter to a similar medium from which ammonium sulfate had been omitted and to which mannitol had been added at a concentration of $1 \mathrm{~g} /$ liter. All of the substrates were filter sterilized before they were added to the basal medium. Growth on the different media was tested in petri dishes by applying approximately $10^{5}$ bacteria from a freshly prepared bacterial suspension with a multipoint inoculator to the surface of the agar. Cultures were incubated at $28^{\circ} \mathrm{C}$, and the growth was recorded after 4 or 5 days.

The results were coded as follows: 1 for heavy or light growth and 0 for absence of growth. Similarity values were calculated by using a simple matching coeffcient (46). A dendrogram was constructed from the similarity matrix by the unweighted pair group method with arithmetic means (UPGMA) (45). In order to test the goodness of fit in the cluster analysis, cophenetic value matrices were calculated and compared with the original similarity matrix that was UPGMA clustered by using the NTSYS-pc analysis package (version 1.8; Exeter Software, Setauket, N.Y.). Matrix correlation was estimated by using the correlation coefficient $r$, which is the normalized Mantel test statistic $Z$

Plant tests. The ability of isolates to nodulate Macroptilium atropurpureum and Onobrychis viciifolia was tested in quadruplicate as described by Vincent (53). The effectiveness of symbiosis with Phaseolus vulgaris was measured by using plants grown under the greenhouse conditions described by Amarger et al. (2). Four pots were used for each isolate, and the plants were harvested after 7 weeks of growth.

16S rDNA sequencing and data analysis. Bacteria were grown on agar slopes of TY medium at $28^{\circ} \mathrm{C}$ for $24 \mathrm{~h}$. The nearly full-length $16 \mathrm{~S}$ rRNA genes were amplified by PCR from lysed cell suspensions with primers fD1 and rD1 as previously described (29). The PCR products were purified with Chroma Spin columns (Clontech, Inc., Palo Alto, Calif.) and were cloned by using a pT7Blue-T vector kit (Novagen, Inc., Madison, Wis.) according to the manufacturers' instructions. Plasmid DNA was purified from Escherichia coli $\mathrm{DH} 5 \alpha \mathrm{F}^{\prime}$ host cells by using a Qiagen Plasmid Midi kit (Qiagen, Hilden, Germany). DNA sequencing was carried out by the dideoxy chain termination method (43) with a T7 sequencing kit (Pharmacia LKB Biotechnology, Orsay, France). Sequencing primers T3 and T7 supplied by Pharmacia and 12 additional primers synthesized by Eurogentec S.A. (Seraing, Belgium) were used to sequence both strands of the $16 \mathrm{~S}$ rDNA molecules. The forward primers used spanned $E$. coli positions 7 to 26,480 to 497,668 to 688,887 to 904,1071 to 1088 , and 1300 to 1320 , and the reverse sequencing primers used spanned positions 297 to 315,515 to 532,838 to 857,1072 to 1092,1249 to 1267 , and 1530 to 1546 .

Nucleotide sequences were aligned by using the Clustal program (19) from the Bisance software (10). A matrix of pairwise distances corrected for multiple base substitutions by the method of Kimura (24) was calculated with the program DNADIST of the Phylogenetic Inference Package (PHYLIP) (12), and a phylogenetic tree was constructed with the NEIGHBOR program (42). A bootstrap confidence analysis was performed by using 200 replications and the SEQBOOT and CONSENSE programs of PHYLIP. A parsimony analysis was performed with the computer program PAUP (Phylogenetic Analysis Using Parsimony) (48), and the robustness of the topologies was evaluated through 200 bootstrap replications (heuristic search).

The GenBank accession numbers for the nucleotide sequences of the $16 \mathrm{~S}$ rRNA genes of the rhizobia and related bacteria used for comparison are as follows: U29386 ( $R$. leguminosarum bv, viciae); X67227 (R. leguminosarum bv. trifolii); U29388 (R. leguminosarum bv. phaseoli); X67233 (R. tropici type IIA); X67234 (R. tropici type IIB); U28916 and U28939 (R. etli); D12793 (R. galegae); X67229 (R. loti); D12797 (Rhizobium huakuii); U07934 (Rhizobium ciceri); L38825 (Rhizobium mediterraneum); U29387 (Rhizobium sp. strain RCR 3618D); X67232 (Rhizobium sp. strain LMG 9509); D01271 (Rhizobium sp. strain OK50); D01268 (Rhizobium sp. strain 113); D12783 (Sinorhizobium meliloti); X67231 (Sinorhizobium fredii); X68388 (Sinorhizobium teranga); X68390 (Sinorhizobium saheli); D12781 (Bradyrhizobium japonicum); X67224 (Agrobacterium rhizogenes); X67223 (Agrobacterium tumefaciens); X67228 (Agrobacterium rubi); X67225 (Agrobacterium vitis); X67221 (Azorhizobium caulinodans); M65249 (Bartonella bacilliformis); X73041 (Blastobacter aggregatus); L26167 (Brucella neotomae); D12786 (Mycoplana dimorpha); D12794 (Ochrobactrum anthropi); D12789 (Phyllobacterium myrsinacearum); M73229 (Rochalimaea henselae); and M11927 (Rochalimaea quintana).

Nucleotide sequence accession numbers. The 16S rDNA sequences of strains $\mathrm{R} 602 \mathrm{sp}^{\mathrm{T}}$ and $\mathrm{H} 152^{\mathrm{T}}$ have been deposited in the GenBank database under accession no. U86343 and U86344, respectively.

\section{RESULTS}

Numerical analysis of phenotypic data. The result of the cluster analysis performed on the 112 strains for 64 phenotypic characteristics is shown in Fig. 1. All of the strains examined, including the Rhizobium and Sinorhizobium reference strains, were linked at a similarity level of $82 \%$. For strains tested in 
TABLE 1. Strains used in this study

\begin{tabular}{|c|c|c|c|c|}
\hline Strain(s) & Host plant source & Geographical origin & Source ${ }^{a}$ & Reference \\
\hline \multirow{2}{*}{\multicolumn{5}{|c|}{ Genomic species 1 (Rhizobium gallicum) strains }} \\
\hline & \\
\hline DC22 & Phaseolus coccineus & & & 14 \\
\hline $\mathrm{PhF} 29$ & Phaseolus vulgaris & Côte d'Or, France & MSDJ & 14 \\
\hline $\mathrm{PhP} 222$ & Phaseolus vulgaris & Tarn et Garonne, France & MSDJ & 14 \\
\hline $\mathrm{R} 602 \mathrm{sp}^{\mathrm{T}}$ & Phaseolus vulgaris & Maine et Loire, France & MSDJ & 14 \\
\hline \multicolumn{5}{|l|}{ Rhizobium gallicum bv. phaseoli strains } \\
\hline PhD12 & Phaseolus vulgaris & Gers, France & MSDJ & 14 \\
\hline $\mathrm{PhI} 21$ & Phaseolus vulgaris & Gers, France & MSDJ & 14 \\
\hline \multicolumn{5}{|l|}{ Genomic species 2 (Rhizobium giardinii) strains } \\
\hline \multicolumn{5}{|l|}{ Rhizobium giardinii bv. gardinii strains } \\
\hline $\begin{array}{l}\mathrm{H} 152^{\mathrm{T}}, \mathrm{H} 153, \mathrm{H} 231, \mathrm{H} 236, \mathrm{H} 241, \mathrm{H} 325, \mathrm{H} 342, \mathrm{H} 412, \\
\text { H423, H462 }\end{array}$ & Phaseolus vulgaris & Côte d'Or, France & MSDJ & 14 \\
\hline Ro1, Ro24, Ro53, Ro61, Ro68, Ro7, Ro70, Ro75, Vp2 & Phaseolus vulgaris & Yvelines, France & MSDJ & 14 \\
\hline \multicolumn{5}{|l|}{ Rhizobium giardinii bv. phaseoli strains } \\
\hline H251 & Phaseolus vulgaris & Côte d'Or, France & MSDJ & 14 \\
\hline PhF28 & Phaseolus vulgaris & Drôme, France & MSDJ & 14 \\
\hline Ro52, Ro67, Ro84, Ro88 & Phaseolus vulgaris & Yvelines, France & MSDJ & 14 \\
\hline Rhizobium sp. (Phaseolus) strain FL27 & Phaseolus vulgaris & Puebla, Mexico & CIFN & 38 \\
\hline \multicolumn{5}{|l|}{ Rhizobium etli strains } \\
\hline CFN $42^{\mathrm{T}}$ & Phaseolus vulgaris & Guanajuato, Mexico & CIFN & 44 \\
\hline СР53, СР91, СР115, СР144, СР145, СР212 & Phaseolus vulgaris & Cipanas, Indonesia & MSDJ & 49 \\
\hline GD112, GD163, GD261, GD274 & Phaseolus vulgaris & Gadog, Indonesia & MSDJ & 49 \\
\hline $\mathrm{BB} 13, \mathrm{BC} 15, \mathrm{BE} 22, \mathrm{BC} 45$ & Phaseolus vulgaris & Burundi & MSDJ & 49 \\
\hline Viking I & Phaseolus vulgaris & Belize & CIFN & 38 \\
\hline Rhizobium leguminosarum bv. viciae ATCC $10004^{\mathrm{T}}$ & Pisum sativum & Illinois & ATCC & \\
\hline Rhizobium leguminosarum bv. trifolii CC2480a & Trifolium subterraneum & Greece & C.S.I.R.O. & \\
\hline \multicolumn{5}{|l|}{ Rhizobium leguminosanum bv. phaseoli strains } \\
\hline 8401 & Phaseolus vulgaris & England & & 55 \\
\hline $\begin{array}{l}\text { H123, H124, H132, H136, H141, H211, H242, H254, } \\
\text { H313, H317, H441 }\end{array}$ & Phaseolus vulgaris & Côte d'Or, France & MSDJ & 14 \\
\hline $\mathrm{PhC} 152$ & Phaseolus vulgaris & Haute Garonne, France & MSDJ & 14 \\
\hline $\mathrm{PhC} 202$ & Phaseolus vulgaris & Gers, France & MSDJ & 14 \\
\hline PhF32 & Phaseolus vulgaris & Côte d'Or, France & MSDJ & 14 \\
\hline $\mathrm{PhI10}$ & Phaseolus vulgaris & Tarn et Garonne, France & MSDJ & 14 \\
\hline $\mathrm{PhN} 842$ & Phaseolus vulganis & Aisne, France & MSDJ & 14 \\
\hline $\mathrm{PhN} 852, \mathrm{PhN} 862$ & Phaseolus vulgaris & Yonne, France & MSDJ & 14 \\
\hline PhP17 & Phaseolus vulgaris & Aisne, France & MSDJ & 14 \\
\hline \multicolumn{5}{|l|}{ Rhizobium tropici strains } \\
\hline \multicolumn{5}{|l|}{ Type IIA strains } \\
\hline CFN 299 & Phaseolus vulgaris & Brazil & CIFN & 44 \\
\hline UMR1178 & Phaseolus vulgaris & Unknown & CIFN & 44 \\
\hline AIREL28, AIREL35 & Phaseolus vulgaris & Lot et Garonne, France & MSDJ & 2 \\
\hline CARA14, CARA56, CARA72 & Phaseolus vulgaris & Landes, France & MSDJ & 2 \\
\hline CESTAS114, CESTAS134, CESTAS221, CESTAS224 & Phaseolus vulgaris & Gironde, France & MSDJ & 2 \\
\hline \multicolumn{5}{|l|}{ Type IIB strains } \\
\hline CIAT $899^{\mathrm{T}}$ & Phaseolus vulgaris & Colombia & CIFN & 44 \\
\hline BR859, BR863 & Leucaena leucocephala & Brazil & CIFN & 44 \\
\hline BA45 & Phaseolus vulgaris & Burundi & MSDJ & 49 \\
\hline Type II strain BR864 & Leucaena leucocephala & Brazil & CIFN & 44 \\
\hline Rhizobium galegae ATCC $43677^{\mathrm{T}}$ & Galega orientalis & Finland & ATCC & 30 \\
\hline \multicolumn{5}{|l|}{ Rhizobium loti strains } \\
\hline NZP2037 & Lotus divaricatus & New Zealand & NZP & 7 \\
\hline NZP2234 & Lotus corniculatus & New Zealand & NZP & 7 \\
\hline Sinorhizobium fredii USDA20 $5^{\mathrm{T}}$ & Glycine $\max$ & People's Republic of China & USDA & 20 \\
\hline Sinorhizobium meliloti RCR2011 & Medicago sativa & Australia & & 7 \\
\hline Sinorhizobium saheli ORS611 & Sesbania grandiflora & Senegal & ORS & 9 \\
\hline Sinorhizobium teranga bv. acaciae ORS1007 & Acacia laeta & Senegal & ORS & 32 \\
\hline Sinorhizobium teranga bv. sesbaniae ORS51 & Sesbania rostrata & Senegal & ORS & 32 \\
\hline $\begin{array}{l}\text { Rhizobium sp. (Acacia) cluster U strains ORS1004 and } \\
\text { ORS1010 }\end{array}$ & Acacia senegal & Senegal & ORS & 9 \\
\hline Agrobacterium tumefaciens $\mathrm{C} 58$ & & & & 25 \\
\hline
\end{tabular}

${ }^{a}$ ATCC, American Type Collection, Rockville, Md.; CIFN, Centro de Investigacion sobre Fijacion de Nitrogeno, Universidad Nacional Autonoma de Mexico, Cuernavaca, Morelos, Mexico; C.S.I.R.O., Division of Plant Industry, Commonwealth Scientific and Industrial Research Organisation, Canberra City, Australian Capital Territory, Australia; MSDJ, Laboratoire de Microbiologie des Sols, Institut National de la Recherche Agronomique, Dijon, France; NZP, Culture Collection, Department of Microbiology and Genetics, Massey University, Palmerston North, New Zealand; ORS, ORSTOM Collection, Institut Français de Recherche Scientifique pour le Développement en Coopération, Dakar, Sénégal; USDA, U.S. Department of Agriculture, Beltsville, Md.

replicate experiments, the similarity values were between 98 and $94 \%$. The strains belonging to the same species, or to the same subgroup in the case of $R$. tropici, clustered independent of their geographical origins, at similarity coefficients varying from 96 to $90 \%$. The only exception was in the species $R$. tropici, in which one type IIA strain, UMR1178, clustered with type IIB. The strains belonging to Rhizobium sp. (Phaseolus) genomic species 1 clustered at a similarity level of $93 \%$, as did 


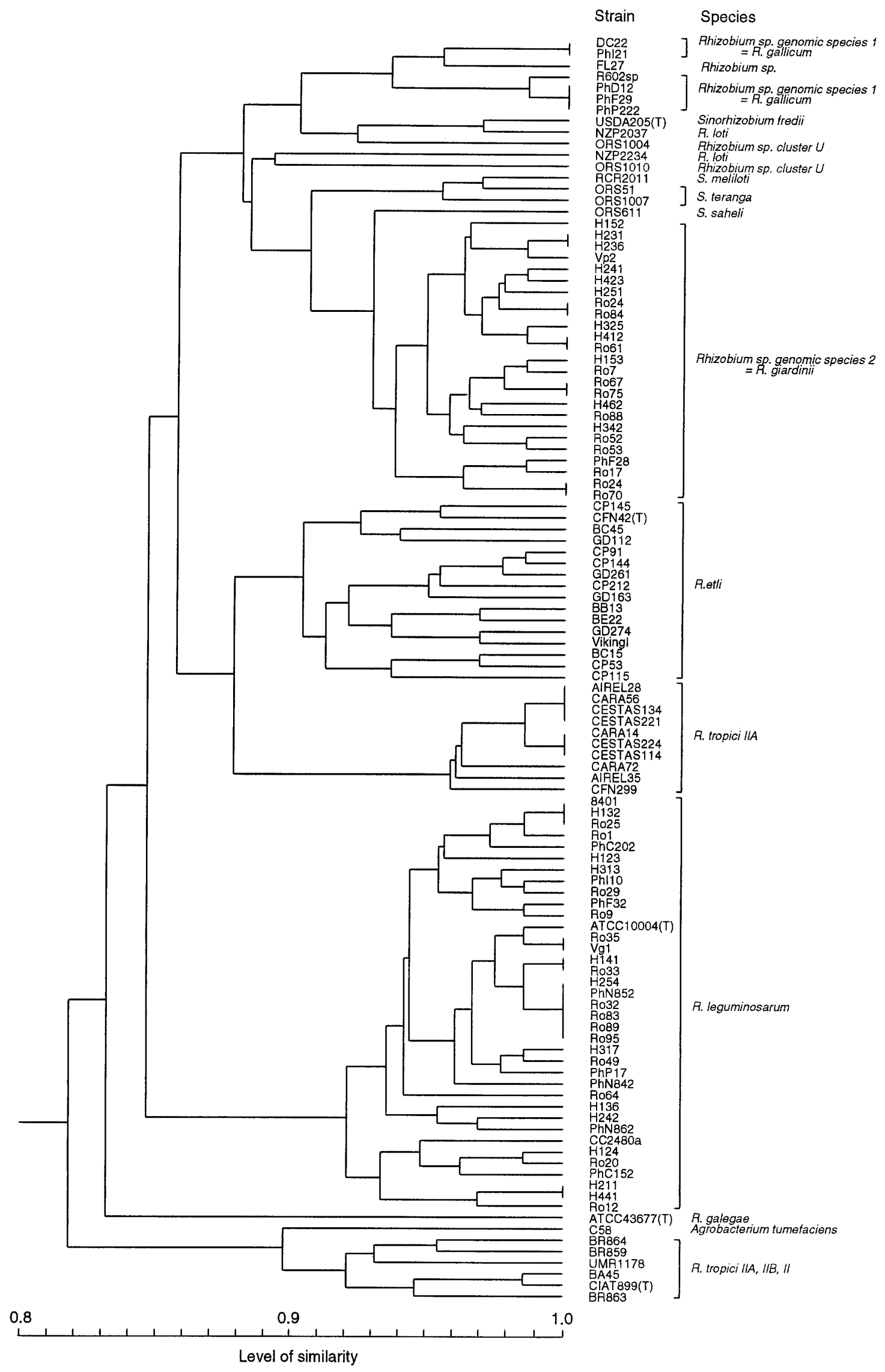

FIG. 1. UPGMA dendrogram showing phenotypic relationships among rhizobia isolated from Phaseolus vulgaris in France and reference strains. The cophenetic correlation $(r)$ value was 0.77 
the 25 strains of genomic species 2. Unclassified strain FL27 was included in the group formed by genomic species $1 . R$. leguminosarum, $R$. etli, and the two subgroups of $R$. tropici each formed a cluster, and each of these clusters was divergent from the three other clusters and from the clusters formed by each genomic species. Most of the levels of similarity between these six clusters and the representative strains of the other Rhizobium and Sinorhizobium species were less than $90 \%$; the only exception was strain ORS611 of $S$. saheli, which grouped with the genomic species 2 cluster at a similarity coefficient of $92 \%$.

All of the strains tested grew on L-arabinose, D-fructose, D-galactose, D-glucose, D-glucosamine, D-glucuronate, lactose, maltose, mannitol, D-mannose, raffinose, L-rhamnose, D-ribose, D-sorbitol, trehalose, xylose, glucitol, inositol, glycerol, soluble starch, and gluconate as carbon sources. Although they all grew on L-arginine, L-alanine, L-asparagine, L-aspartate, L-cysteine, L-cystine, L-glutamine, L-glutamic acid, L-histidine, L-proline, L-isoleucine, L-leucine, L-lysine, L-methionine, Lphenylalanine, L-proline, L-serine, L-threonine, and L-valine as nitrogen sources, differences in growth were noticed among the isolates belonging to the different bean-nodulating species. Isolates of genomic species 2 grew well on these amino acids, whereas the growth of $R$. leguminosarum and $R$. etli was very slight and the growth of genomic species 1 and $R$. tropici was intermediate. Table 2 shows the most relevant phenotypic features that differentiate the species studied. Utilization of erythritol, utilization of dulcitol, and utilization of lactate are the most useful traits for differentiating the species that nodulate beans. Besides tolerance to nalidixic acid, to which all of the bean-nodulating rhizobia except $R$. leguminosarum were resistant, tolerance to the antibiotics tested, tolerance to salinity, and tolerance to acidity and alkalinity were found to be more strain specific than species specific.

Symbiotic properties. The isolates belonging to genomic species 1 and 2 were tested for their ability to nodulate $\mathrm{Ma}$ croptilium atropurpureum and Onobrychis viciifolia. The results are shown in Table 3 along with the results of nodulation tests previously performed with Phaseolus vulgaris and Leucaena leucocephala (14). All of the isolates nodulated Macroptilium atropurpureum, but the time at which the nodules appeared varied with the isolate. For most of the isolates, nodules appeared 10 to 15 days after inoculation, and by 20 days all of the plants were nodulated. For other isolates, nodules appeared only 4 to 6 weeks after inoculation. The isolates in which delayed nodulation of Macroptilium atropurpureum was observed were the isolates which had been previously found to be unable to nodulate $L$. leucocephala. Among the isolates which nodulated both Macroptilium atropurpureum and L. leucocephala, only those belonging to genomic species 1 were able to nodulate Onobrychis viciifolia. All of the isolates of genomic species 1, whatever their nodulation phenotype, formed an effective symbiosis with Phaseolus vulgaris, whereas for genomic species 2 isolates the effectiveness differed with the nodulation phenotype of the isolate. In this species the isolates which nodulated Macroptilium atropurpureum and L. leucocephala were totally ineffective with Phaseolus vulgaris. The dry matter yield was the same as the dry matter yield of uninoculated control plants, and the nodules formed were numerous, small (1 to $2 \mathrm{~mm}$ in diameter), and white or very pale green. The genomic species 2 isolates which did not nodulate $L$. leucocephala and showed delayed nodulation of Macroptilium atropurpureum were very weakly effective. The dry matter yield which they gave when they were inoculated onto Phaseolus vulgaris was greater $(P=0.058)$ than the dry matter yield of the uninoculated control. The nodules resembled nodules formed by efficient strains; they were almost as big ( 2 to $4 \mathrm{~mm}$ in diameter), but were dark green instead of red.

Nucleotide sequence analysis of $16 \mathrm{~S}$ rDNA. The nearly complete 16S rRNA gene sequences of strains R602sp ${ }^{\mathrm{T}}$ and $\mathrm{H} 152^{\mathrm{T}}$ were determined. The number of nucleotide differences between the two strains was 64 , which represented a similarity value of $95.7 \%$. These sequences differed from those of 34 reference strains belonging to the $\alpha-2$ subclass of the class Proteobacteria, including the sequences of 6 rhizobial strains isolated from Phaseolus vulgaris (Table 4). The sequence of strain R602 $\mathrm{sp}^{\mathrm{T}}$ was most similar to that of Rhizobium species 3 (Pterocarpus) strain OK50 (level of similarity, 98.4\%; 23 nucleotide differences). The other most similar $16 \mathrm{~S}$ rDNAs were those of $R$. etli and $R$. leguminosarum (Table 4). Strain $\mathrm{H}_{152} 2^{\mathrm{T}}$ showed relatively low sequence similarities with the reference strains examined, with similarity values ranging from 96.8 to $88.6 \%$. The highest values were the values obtained with the 16S rDNAs of $S$. meliloti and $S$. fredii (46 and 49 nucleotide differences, respectively).

The phylogenetic tree constructed by the distance matrix method with the neighbor-joining (NJ) algorithm is shown in Fig. 2. Strains R602sp ${ }^{T}$ and OK50 were clustered on a monophyletic lineage in $95 \%$ of the bootstrap replicates. These strains formed a cluster together with $R$. leguminosarum, $R$. etli, the $R$. tropici-Agrobacterium rhizogenes subgroup, and Rhizobium sp. (Phaseolus) strain RCR3618D (bootstrap value, $99 \%$ ). Strain $\mathrm{H} 152^{\mathrm{T}}$ formed an independent lineage and was distantly related to the other bean-nodulating strains. The organisms most closely, but moderately, related to this lineage were $R$. galegae and some Agrobacterium species which formed a subgroup together with Blastobacter aggregatus in $90 \%$ of the bootstrap replicates in the $\mathrm{NJ}$ analysis. The branch point of strain $\mathrm{H} 152^{\mathrm{T}}$, which was located outside the $R$. galegaeAgrobacterium subgroup, was supported by a bootstrap value of $94 \%$. To assess the reliability of the branch points of $\mathrm{R} 602 \mathrm{sp}^{\mathrm{T}}$ and $\mathrm{H} 152^{\mathrm{T}}$, the data were also analyzed by performing a parsimony analysis (data not shown). While the main groups and the species pair subgroups remained stable, there were some changes in position and branching order, as previously reported by Willems and Collins (54). The bootstrap confidence values obtained with the parsimony method were generally lower than those obtained with the NJ method. However, the results corroborated the phylogenetic positions of strains R602sp ${ }^{\mathrm{T}}$ and $\mathrm{H} 152^{\mathrm{T}}$ estimated from the $\mathrm{NJ}$ analysis.

\section{DISCUSSION}

In order to avoid as much as possible inconsistency in bacterial taxonomy, the polyphasic approach is now recommended for the creation of new taxa (51). This approach requires the integration of phenotypic genotypic and phylogenetic information. We used this approach to determine the taxonomic relationships of two new groups of rhizobia nodulating members of the genus Phaseolus obtained from several locations in France. The genotypic data were obtained during ecological investigations in which we used DNA-based methods to examine the diversity of rhizobial isolates $(14,28)$. Plasmid profiling, which is highly discriminatory for many Rhizobium species, was used to categorize Rhizobium field populations isolated from Phaseolus nodules. A sample representative of the plasmid profile diversity was further characterized by whole-genome restriction fragment analysis and by analysis of the patterns of restriction fragments hybridizing to labeled genomic probes. The use of two chromosomal probes specific for $R$. leguminosarum and $R$. etli $(26,28)$ allowed us to identify a group of isolates which lacked homology to these probes and corre- 


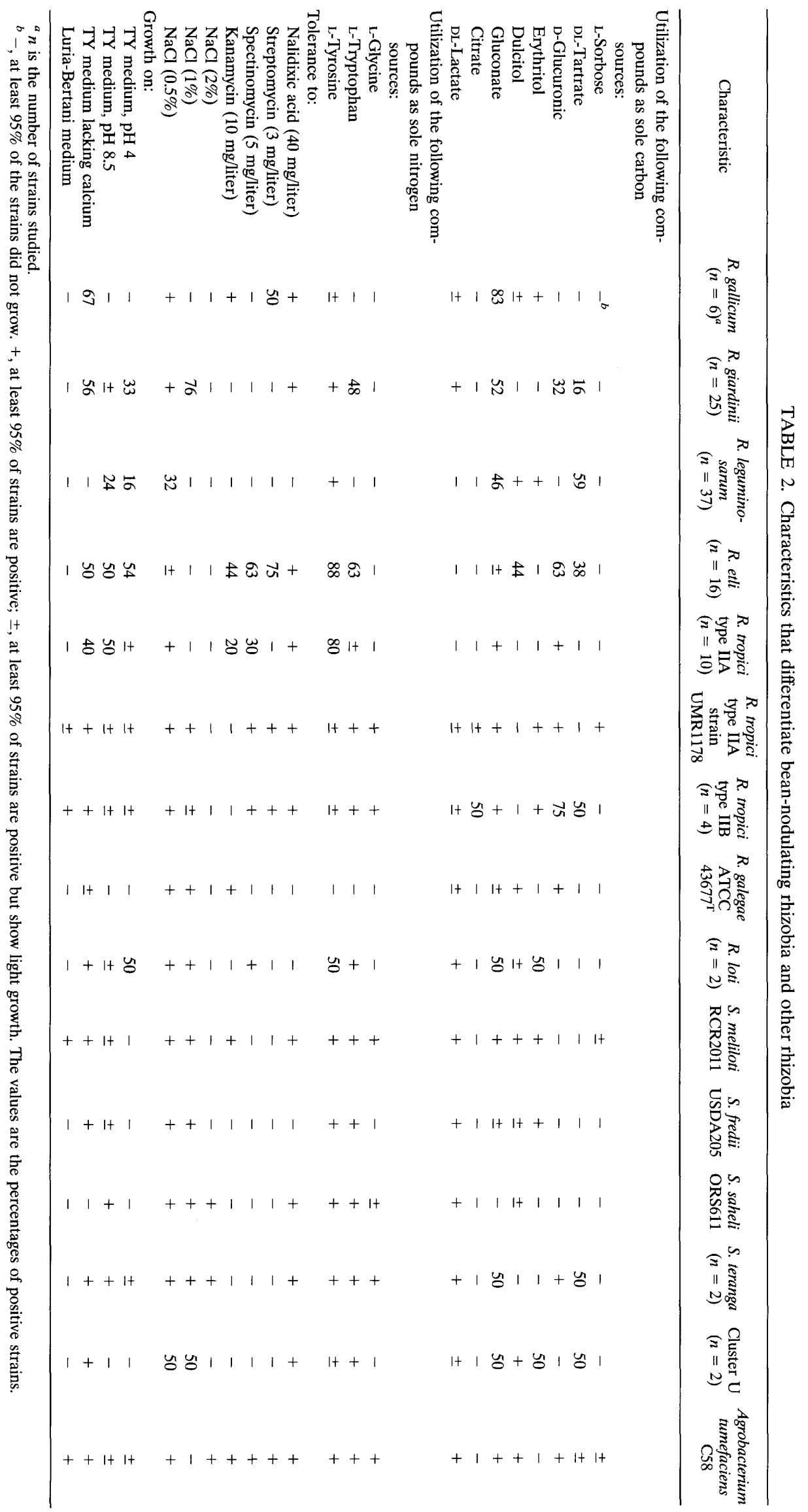


TABLE 3. Nodulation and nitrogen fixation by isolates belonging to R. gallicum and $R$. giardinii

\begin{tabular}{|c|c|c|c|c|c|}
\hline \multirow[b]{2}{*}{ Strains } & \multicolumn{4}{|c|}{ Nodulation of: } & \multirow{2}{*}{$\begin{array}{c}\text { Nitrogen fixation } \\
\text { with Phaseolus } \\
\text { vulgaris }^{b}\end{array}$} \\
\hline & $\begin{array}{l}\text { Phaseolus } \\
\text { vulgaris }\end{array}$ & $\begin{array}{l}\text { L. leuco- } \\
\text { cephala }\end{array}$ & $\begin{array}{l}\text { Macroptilium } \\
\text { atropurpureum }\end{array}$ & $\begin{array}{l}\text { Onobrychis } \\
\text { viciifolia }\end{array}$ & \\
\hline \multicolumn{6}{|l|}{ R. gallicum strains } \\
\hline R602sp, DC22, PhP222, PhF29 & + & + & $+(<20 \text { days })^{c}$ & + & + \\
\hline $\mathrm{PhI21,} \mathrm{PhD} 12$ & + & - & $+(30-40$ days $)$ & - & + \\
\hline \multicolumn{6}{|l|}{ R. giardinii strains } \\
\hline $\begin{array}{l}\text { H152 }{ }^{\mathrm{T}}, \mathrm{H} 153, \mathrm{H} 231, \mathrm{H} 236, \mathrm{H} 241, \mathrm{H} 325, \mathrm{H} 342, \mathrm{H} 412, \mathrm{H} 423, \mathrm{H} 462 \\
\text { Ro17, Ro24, Ro53, Ro61, Ro68, Ro7, Ro70, Ro75, Vp2 }\end{array}$ & + & + & $+(<20$ days $)$ & - & - \\
\hline H251, PhF28, Ro52, Ro67, Ro84, Ro88 & + & - & $+(30-40$ days $)$ & - & \pm \\
\hline
\end{tabular}

sponded to isolates in which a megaplasmid (length, more than $1,000 \mathrm{~kb}$ ) had been observed. As determined by ribotyping, these isolates were found to be distributed in two genomic groups which themselves were polymorphic (14). To further characterize isolates assigned to the two groups, total cellular DNA of a member of each group was used as a probe. Under stringent hybridization conditions, each probe was found to be group specific and did not hybridize with DNAs of $R$. leguminosarum, $R$. etli, or $R$. tropici strains. The levels of DNA relatedness between strains that were representative of the genomic diversity found in each group and the type strains of Rhizobium species were less than $21 \%$. The level of DNA relatedness between the two groups was $18 \%$. Each group was thus identified as a new genomic species (27). The minimum levels of DNA relatedness between strains in genomic species 1 and genomic species 2 were 76 and $74 \%$, respectively (27).

In the present study, we compared phenotypic traits of isolates belonging to the two genomic species to phenotypic traits of isolates representing the genotypic diversity found in French isolates of $R$. leguminosarum bv. phaseoli and $R$. tropici and to phenotypic traits of reference strains. To represent the diversity of $R$. etli, we chose isolates from diverse geographical areas. The phenotypic analysis allowed us to cluster isolates from bean nodules into six different phena. Each phenon contained isolates that had a common genotype. The two phena corresponding to the two genomic species were well-delineated. The genomic species 1 cluster included unclassified strain FL27, a strain which was isolated from a Phaseolus nodule in Mexico (38). We previously observed that the $16 \mathrm{~S}$ rDNA type of this strain was similar if not identical to the $16 \mathrm{~S}$ rDNA type of genomic species 1 isolates $(25,27)$. Taken together, these results suggest that strain FL27 may belong to genomic species 1 , but more data are needed to definitely assign this strain to the species. The $R$. leguminosarum phenon was well-differentiated from the $R$. etli phenon. This indicates that unlike the MLEE analysis performed by Eardly et al. (11), the phenotypic analysis permitted distinction between the $R$. etli and $R$. leguminosarum $16 \mathrm{~S}$ rRNA alleles. However, this must be checked with a more diversified sample of strains. Isolates belonging to $R$. tropici formed two phena which corresponded to the two subgroups described by Martinez-Romero et al. (36) and supported the division of the members of the species into two subgroups. The phenotypic analysis showed that the different groups of bean-nodulating rhizobia that we identified as genomic species were also phenotypically distinct from each other and from the Rhizobium species described previously and thus should be assigned to new species.

The results of the 16S rDNA sequence comparison and phylogenetic analysis support the creation of new species. Genomic species 1 clustered with the three previously recognized species of bean-nodulating rhizobia. Mainly on the basis of 16S rRNA gene analysis data, it has been suggested recently that only $R$. leguminosarum, which is the type species of the genus Rhizobium, $R$. etli, $R$. tropici, and Agrobacterium rhizogenes should represent the genus Rhizobium (56). R. loti and the other closely related species, $R$. huakuii, $R$. ciceri, and $R$. mediterraneum, should be assigned to a new genus, for which the name "Mesorhizobium" has been proposed (31). R. galegae, which is more closely related to some Agrobacterium species, does not fit into any of the five generic groups of rhizobia (the genera Rhizobium, Sinorhizobium, Bradyrhizobium, Azorhizobium, and "Mesorhizobium"). It has been suggested that $R$. galegae should not be reclassified in a new genus until closely related species are identified on this lineage (56). The levels of $16 \mathrm{~S}$ rDNA similarity (98 to $96.6 \%$ ) between strain R602sp ${ }^{\mathrm{T}}$ and the members of the species that form the genus Rhizobium sensu stricto as defined above were comparable to the levels of $16 \mathrm{~S}$ rDNA similarity among these species (99.8 to $97.6 \%$ ) and were higher than the levels of $16 \mathrm{~S}$ rDNA similarity between $\mathrm{R} 602 \mathrm{sp}^{\mathrm{T}}$ and other rhizobia $(<96.2 \%)$. In particular, the levels of similarity between R602 $\mathrm{sp}^{\mathrm{T}}$ and $R$. leguminosarum (97.5\%) and between $\mathrm{R} 602 \mathrm{sp}^{\mathrm{T}}$ and $R$. etli $(98 \%)$ indicated that the genomic species represented by $\mathrm{R} 602 \mathrm{sp}^{\mathrm{T}}$ should be classified in the same genus as these two species. The analysis of the whole 16S rRNA gene sequence placed $R 602 \mathrm{sp}^{\mathrm{T}}$ on a lineage independent from the lineages formed by $R$. leguminosarum, $R$. etli, and $R$. tropici. On the basis of an analysis of a 246-bp region from the $5^{\prime}$ part of the $16 \mathrm{~S}$ rRNA gene, R602 $\mathrm{sp}^{\mathrm{T}}$ and $R$. etli were previously found to be tightly clustered (27). This difference between results confirms that the partial 16S rDNA sequences analyzed were not fully representative of the whole gene and that phylogenetic positions inferred from partial $16 \mathrm{~S}$ rDNA sequence analyses should be considered more indicative than definitive.

Strain R602sp ${ }^{\mathrm{T}}$ branched with an unclassified Rhizobium strain, OK50, which was isolated from nodules of Pterocarpus klemmei in Japan (37). R602sp ${ }^{\mathrm{T}}$ exhibited the highest level of $16 \mathrm{~S}$ rDNA sequence similarity with this strain $(98.4 \%)$. The levels of $16 \mathrm{~S}$ rDNA homology between R602sp ${ }^{\mathrm{T}}$ and strains which cannot be differentiated by $16 \mathrm{~S}$ rRNA gene restriction 


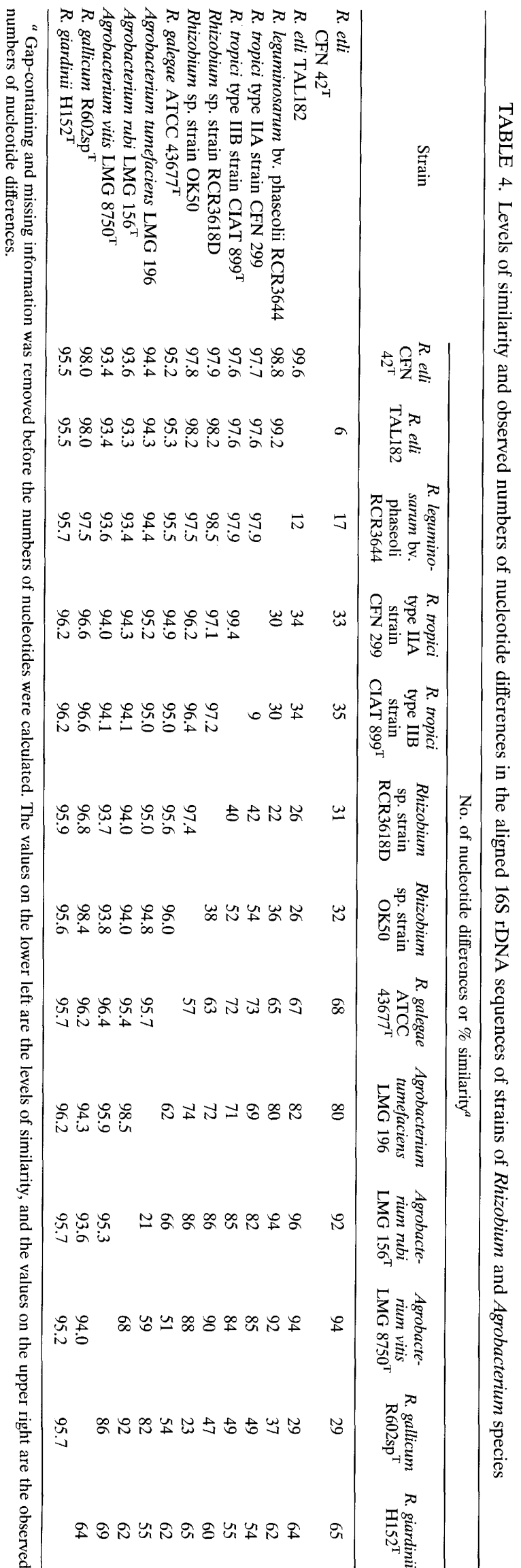

analysis are also probably high. Besides Rhizobium sp. (Phaseolus) strain FL27, which belonged to the same phenon as $\mathrm{R} 602 \mathrm{sp}^{\mathrm{T}}$, as shown above, three strains isolated from Onobrychis spp. and one strain isolated from Oxytropis riparia were reported to be indistinguishable from $\mathrm{R} 602 \mathrm{sp}^{T}$ on the basis of $16 \mathrm{~S}$ rRNA gene restriction analysis data (29). According to Stackebrandt and Goebel (47), organisms exhibiting more than 97\% rRNA similarity may belong to the same species. Rhizobium sp. strain OK50 and the five strains which had the same $16 \mathrm{~S}$ rDNA type as R602sp ${ }^{T}$ might belong to the same species as R602 $\mathrm{sp}^{\mathrm{T}}$. However, as a minimum level of DNA-DNA homology between strains of 60 to $70 \%$ is needed for the strains to be classified in the same species, we need additional DNA relatedness data to establish whether these unclassified rhizobia belong to the same species as the genomic species 1 isolates. Nevertheless, these results indicate that this species, or at least organisms more closely related to it than to other recognized Rhizobium species, may not be limited to France and nodules of Phaseolus spp. but may be widely distributed across continents and among various host plant genera.

The phylogenetic trees constructed from the whole $16 \mathrm{~S}$ rRNA gene analysis indicated that strain $\mathrm{H} 152^{\mathrm{T}}$ was more closely related to $R$. galegae, to unclassified Rhizobium (Mimosa) species 1 strain 113 (37), and to several Agrobacterium species than to any other rhizobia or related bacteria. In particular, $\mathrm{H} 152^{\mathrm{T}}$ did not have a close relationship with $R$. loti, which did not corroborate our previous data based on partial 16S rRNA gene sequencing (27). This is another example of the lack of accuracy found when a partial sequence from the $5^{\prime}$ part of the $16 \mathrm{~S}$ rRNA gene is analyzed. Strain $\mathrm{H} 152^{\mathrm{T}}$ was not closely related enough to $R$. galegae (16S rDNA similarity, $95.7 \%$ ) to place these organisms in the same genus. However, the species represented by strain $\mathrm{H} 152^{\mathrm{T}}$ is not phylogenetically closely related to typical members of the genus Rhizobium, with $16 \mathrm{~S}$ rDNA nucleotide sequence similarity values ranging from 96.2 to $95.5 \%$. The levels of similarity between the $16 \mathrm{~S}$ rDNA nucleotide sequences of $\mathrm{H}_{152^{\mathrm{T}}}$ and the Agrobacterium species which branched with $R$. galegae ranged from 96.2 to $95.2 \%$. Again, these values are too low to place $\mathrm{H}_{152^{\mathrm{T}}}$ in the genus Agrobacterium.

Based on the phenotypic and phylogenetic data reported in this paper, we propose that two new Rhizobium species should be created for the two genotypically distinct species that we described previously. Genomic species 1 deserves separate species status in the genus Rhizobium, and we propose the name $R$. gallicum for it. Genomic species 2 was clearly separated by both phenotypic and molecular characteristics from all of the previously described species and genera of rhizobia. However, before a new genus name is created, it is necessary to identify other species that are closely related to genomic species 2 and also to $R$. galegae, its closest neighbor. As long as the relationships between these rhizobia are not clarified at the genus level, it seems advisable to classify genomic species 2 as a new species of the genus Rhizobium, and we propose the name $R$. giardinii for this taxon.

On the basis of the results of a restriction fragment length polymorphism analysis of symbiotic gene regions, we showed previously that genomic species 1 and 2 were each associated with two distinct symbiotic genotypes (14). One of these genotypes was characteristic of the species, and the other was common to the two species. The two symbiotic genotypes specific to the two species were characterized by a lack of homology with a nodB gene probe from CFN42, the type strain of $R$. etli, under the high-stringency hybridization conditions which we used for identifying the symbiosis plasmid of $R$. leguminosarum bv. phaseoli and $R$. etli bv. phaseoli (28). However, under less 


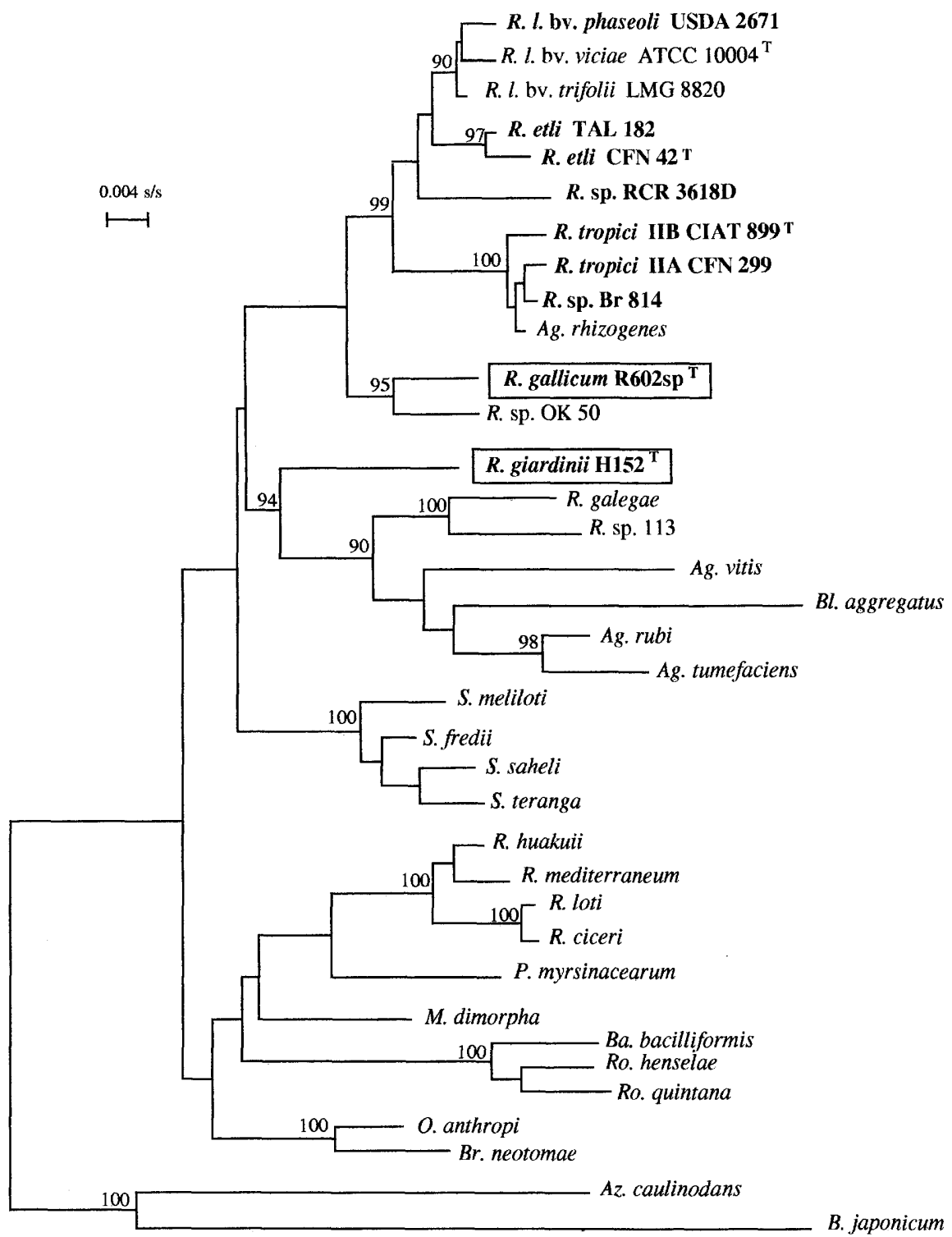

FIG. 2. Phylogenetic tree obtained by the NJ method showing the relationships among rhizobia and several related taxa belonging to the alpha-2 subgroup of the class Proteobacteria. Significant bootstrap probability values are indicated at the branch points (only values greater than $90 \%$ are shown). Abbreviations: $R$., Rhizobium; R. l., Rhizobium leguminosarum; Ag., Agrobacterium; S., Sinorhizobium; B., Bradyrhizobium; Az., Azorhizobium; Bl., Blastobacter; P., Phyllobacterium; Ro., Rochalimaea; Ba., Bartonella; M., Mycoplana; O., Ochrobactrum; Br., Brucella. The following unmarked strains were used for the phylogenetic analysis: Agrobacterium rhizogenes LMG 152, Agrobacterium rubi LMG $156^{\mathrm{T}}$, Agrobacterium tumefaciens LMG 196, Agrobacterium vitis LMG $8750^{\mathrm{T}}$, Azorhizobium caulinodans LMG $^{6465^{\mathrm{T}}}$, Bradyrhizobium japonicum IAM $12608^{\mathrm{T}}$, Brucella neotomae ATCC 23459 , Mycoplana dimorpha IAM $13154^{\mathrm{T}}$, Ochrobactrum anthropi IAM $14119^{\mathrm{T}}$, Phyllobacterium myrsinacearum IAM $13584^{\mathrm{T}}$, R. ciceri UPM-Ca $7^{\mathrm{T}}$, R. galegae IAM $13631^{\mathrm{T}}\left(=\right.$ ATCC $\left.43677^{\mathrm{T}}\right)$, R. huakuii IAM $1611^{\mathrm{T}}$, R. loti LMG $6125^{\mathrm{T}}$, R. mediterraneum UPM-Ca36 ${ }^{\mathrm{T}}$, Rhizobium sp. strain LMG 9509 (= BR814), Rochalimaea quintana Fuller; S. fredii LMG $6217^{\mathrm{T}}$ (= USDA $205^{\mathrm{T}}$ ), S. meliloti IAM $12611^{\mathrm{T}}, S$. saheli LMG $7837^{\mathrm{T}}$, and $S$. teranga LMG $7834^{\mathrm{T}}$. The rhizobia that nodulate Phaseolus vulgaris are in boldface type. Scale bar $=0.004$ substitution per site $(\mathrm{s} / \mathrm{s})$.

stringent conditions, homology to the nod probe was obtained and the hybridization signal was found to be located on a plasmid which ranged in size from 250 to $350 \mathrm{~kb}$ depending on the isolate, which indicated that the nod genes were plasmidic. In genomic species 1 , the isolates with low levels of homology to the nod gene probe had one copy of the nifH gene localized on the same plasmid as the $\operatorname{nod} B$ gene, which was thus identified as the symbiotic plasmid. These isolates corresponded to those found in the present study to be capable of nodulating Phaseolus vulgaris, L. leucocephala, and Onobrychis viciifolia and to exhibit early nodulation with Macroptilium atropurpureum. In genomic species 2 , the isolates with low levels of homology to the nod gene probe lacked homology to the nifH gene even under low-stringency hybridization conditions. They corresponded to the isolates that nodulated Phaseolus vulgaris and $L$. leucocephala, exhibited early nodulation with Macroptilium atropurpureum, and did not fix nitrogen with Phaseolus vulgaris. Conversely, the isolates with the symbiotic genotype that was common to the two genomic species showed homology to the nodB gene probe and contained three copies of the nifH gene, which is typical of the symbiotic plasmid of $R$. leguminosarum bv. phaseoli and $R$. etli bv. phaseoli. This genotype was associated in both genomic species with the nodulation phenotype characterized by nodulation of the genus Phaseolus and late nodulation of Macroptilium atropurpureum, which is also the nodulation phenotype of $R$. leguminosarum 
bv. phaseoli and $R$. etli bv. phaseoli. The genomic species 1 and 2 isolates with the symbiotic genotype and nodulation phenotype similar to the symbiotic genotype and nodulation phenotype of $R$. leguminosarum bv. phaseoli and $R$. etli bv. phaseoli likely received their symbiotic plasmid by horizontal transfer from the $R$. leguminosarum strains which were present in the fields in which the isolates originated. Similar, if not identical, symbiotic plasmids can therefore be harbored by field isolates belonging to four different species, which provides circumstantial evidence that interspecific transfer of a symbiotic plasmid occurred in natural environments. However, when this type of symbiotic plasmid was harbored in the genomic species 2 chromosomal background, it provided only a weak nitrogen fixation capacity to the isolates.

Since strains belonging to the same genomic species can harbor genotypically and phenotypically different symbiotic plasmids, we propose, by analogy to $R$. leguminosarum (23) and $S$. teranga (32), that the new species should be subdivided into biovars. As the genotypic and nodulation characteristics conferred by one of the symbiotic plasmids are common to the two genomic species and to $R$. leguminosarum bv. phaseoli and $R$. etli bv. phaseoli, we propose the epithet phaseoli for this biovar. The host range conferred by each plasmid that is characteristic of its own species is not limited to a single legume genus and has not been fully explored yet; therefore, it would be misleading to give to the biovars names derived from single host plants. Since the two species that we describe here each harbored a specific symbiotic plasmid, we propose that the names of the species should be used for the biovars. $R$. gallicum is thus divided into $R$. gallicum bv. gallicum and $R$. gallicum bv. phaseoli, and $R$. giardinii is divided into $R$. giardinii bv. giardinii and $R$. giardinii bv. phaseoli.

Description of Rhizobium gallicum sp. nov. Rhizobium gallicum (gal'li.cum. L. adj. gallicum, from Gallia, the country of origin, France). Gram-negative, aerobic, motile, non-sporeforming rods that are 0.5 to $0.7 \mu \mathrm{m}$ wide by 1.5 to $2 \mu \mathrm{m}$ long. Colonies on Bergersen's medium are circular, convex, white, semitranslucent, and usually 2 to $4 \mathrm{~mm}$ in diameter within 2 to 3 days at $28^{\circ} \mathrm{C}$. These bacteria are unable to grow in Luria broth. They utilize a wide range of carbohydrates as sole carbon sources for growth. They grow on erythritol and are resistant to nalidixic acid. At the molecular level this species can be differentiated from other Rhizobium species and related genera by the results of DNA-DNA hybridization experiments, by the sequence of the $16 \mathrm{~S}$ rRNA gene, and by amplified $16 \mathrm{~S}$ rDNA restriction analysis data.

$R$. gallicum bv. gallicum strains nodulate Phaseolus spp., $L$. leucocephala, Macroptilium atropurpureum, and Onobrychis viciifolia. They fix nitrogen with Phaseolus vulgaris. At the molecular level this biovar can be differentiated from the other biovar by the presence of a single copy of the nitrogenase reductase gene nifH.

$R$. gallicum bv. phaseoli strains nodulate Phaseolus spp. They can also nodulate Macroptilium atropurpureum but do so with a delay of at least 1 month after inoculation. They do not nodulate L. leucocephala or Onobrychis viciifolia. They fix nitrogen with Phaseolus vulgaris. At the molecular level this biovar can be differentiated from the other biovar by the presence of three copies of the nitrogenase reductase gene nifH.

Strain R602sp, which was isolated from a nodule of Phaseolus vulgaris, is the type strain. This strain has the characteristics described above for $R$. gallicum bv. gallicum. Strain R602sp ${ }^{T}$ and all of the other strains of $R$. gallicum have been deposited in the culture collection of the Laboratoire de Microbiologie des Sols, Institut National de la Recherche Agronomique, Di- jon, France. Strain R602sp $\mathrm{s}^{\mathrm{T}}$ has been deposited as strain MSDJ1109 ${ }^{\mathrm{T}}$.

Description of Rhizobium giardinii sp. nov. Rhizobium giardinii (giar.di'ni.i. N.L. gen. n. giardinii, of Giardini, in memory of Roberto Giardini, a Brazilian rhizobiologist who first isolated the organism during a doctoral stay in the Laboratoire de Microbiologie des Sols). Gram-negative, aerobic, motile, nonspore-forming rods that are 0.5 to $0.7 \mu \mathrm{m}$ wide by 1.6 to $2.2 \mu \mathrm{m}$ long. Colonies on Bergersen's medium are circular, convex, white, translucent, and usually 2 to $4 \mathrm{~mm}$ in diameter within 2 to 3 days at $28^{\circ} \mathrm{C}$. These bacteria are unable to grow in Luria broth. They utilize a wide range of carbohydrates as sole carbon sources for growth and a wide range of amino acids as sole nitrogen sources. They grow on lactate but not on erythritol or dulcitol and are resistant to nalidixic acid. At the molecular level this species can be differentiated from other Rhizobium species and related genera by the results of DNA-DNA hybridization experiments, by the sequence of the 16S rRNA gene, and by amplified $16 \mathrm{~S}$ rDNA restriction analysis data.

$R$. giardinii bv. giardinii strains nodulate Phaseolus spp., $L$. leucocephala, and Macroptilium atropurpureum. They are not able to fix nitrogen with Phaseolus vulgaris. At the molecular level this biovar can be differentiated from the other biovar by the absence of hybridization with a probe containing the nitrogenase reductase gene nifH, even under very low-stringency conditions.

$R$. giardinii bv. phaseoli strains nodulate Phaseolus spp. They can also nodulate Macroptilium artropurpureum but do so with a delay of at least 1 month after inoculation. They do not nodulate $L$. leucocephala. They are only weakly efficient in nitrogen fixation with Phaseolus vulgaris, At the molecular level this biovar can be differentiated from the other biovar by the presence of three copies of the nitrogenase reductase gene nifH.

Strain $\mathrm{H} 152$, which was isolated from a nodule of Phaseolus vulgaris grown in Bretennieres, France, is the type strain. This strain has the characteristics described above for $R$. giardinii bv. giardinii. Strain $\mathrm{H} 152^{\mathrm{T}}$ and all of the other strains of $R$. giardinii have been deposited in the culture collection of the Laboratoire de Microbiologie des Sols, Institut National de la Recherche Agronomique, Dijon, France. Strain $\mathrm{H} 152^{\mathrm{T}}$ has been deposited as strain MSDJ0144 ${ }^{\mathrm{T}}$.

\section{ACKNOWLEDGMENTS}

We thank M. Bours and G. Sommer for their excellent technical assistance. We are grateful to S. I. Mazurier for her helpful support in nucleotide sequencing and to F. Dessaint for his help in the numerical taxonomy analysis.

This work was supported in part by the Conseil Régional de Bourgogne.

\section{REFERENCES}

1. Amarger, N. Unpublished data.

2. Amarger, N., M. Bours, F. Revoy, M. R. Allard, and G. Laguerre. 1994. Rhizobium tropici nodulates field-grown Phaseolus vulgaris in France. Plant Soil 161:147-156.

3. Bergersen, F. J. 1961. The growth of Rhizobium in synthetic media. Aust. J. Biol. Sci. 14:349-360.

4. Beringer, J. E. 1974. R factor transfer in Rhizobium leguminosanum. J. Gen. Microbiol. 84:188-198.

5. Beynon, J. L., and D. P. Josey. 1980. Demonstration of heterogeneity in natural population of Rhizobium phaseoli using variation in intrinsic antibiotic resistance. J. Gen. Microbiol. 118:437-442.

6. Brom, S. E Martinez, G. Davila, and R. Palacios, 1988. Narrow- and broad-host range symbiotic plasmids of Rhizobium spp. strains that nodulate Phaseolus vulgaris. Appl. Environ. Microbiol. 54:1280-1283.

7. Crow, V. L., B. D. W. Jarvis, and R. M. Greenwood. 1981. Deoxyribonucleic acid homologies among acid-producing strains of Rhizobium. Int. J. Syst. Bacteriol. 31:152-172. 
8. Davis, E. O., and A. W. B. Johnston. 1990. Analysis of three nodD genes in Rhizobium leguminosarum biovar phaseoli; nod $\mathrm{D} 1$ is preceded by nol $\mathrm{E}$, a gene whose product is secreted from the cytoplasm. Mol. Microbiol. 4:921932.

9. De Lajudie, P., A. Willems, B. Pot, D. Dewettinck, G. Maestrojuan, M. Neyra, M. D. Collins, B. Dreyfus, K. Kersters, and M. Gillis. 1994. Polyphasic taxonomy of rhizobia: emendation of the genus Sinorhizobium and description of Sinorhizobium meliloti comb. nov., Sinorhizobium saheli sp. nov., and Sinorhizobium teranga sp. nov. Int. J. Syst. Bacteriol. 44:715-733.

10. Dessen, P., C. Fondrat, C. Valencien, and C. Mugnier. 1990. Bisance: a French service for access to biomolecular sequence databases. CABIOS 6:355-356.

11. Eardly, B. D., F. Wang, T. S. Whittam, and R. K. Selander. 1995. Species limits in Rhizobium populations that nodulate the common bean (Phaseolus vulgaris). Appl. Environ. Microbiol. 61:507-512.

12. Felsenstein, J. 1989. PHYLIP-phylogeny inference package (version 3.2). Cladistics 5:164-166.

13. Geniaux, E., M. Flores, R. Palacios, and E. Martinez. 1995. Presence of megaplasmids in Rhizobium tropici and further evidence of differences between the two $R$. tropici subtypes. Int. J. Syst. Bacteriol. 45:392-394.

14. Geniaux, E., G. Laguerre, and N. Amarger. 1993. Comparison of geographically distant populations of Rhizobium isolated from root nodules of Phaseolus vulgaris. Mol. Ecol. 2:295-302.

15. Gibbins, A. M., and K. F. Gregory. 1972. Relatedness among Rhizobium and Agrobacterium species determined by three methods of nucleic acid hybridization. J. Bacteriol. 111:129-141.

16. Graham, P. H. 1964. The application of computer techniques to the taxonomy of the root-nodule bacteria of legumes. J. Gen. Microbiol. 35:511-517.

17. Graham, P. H., M. J. Sadowsky, H. H. Keyser, Y. M. Barnet, R. S. Bradley, J. E. Cooper, D. J. De Ley, B. D. W. Jarvis, E. B. Roslycky, B. W. Strijdom, and J. P. W. Young. 1991. Proposed minimal standards for the description of new genera and species of root- and stem-nodulating bacteria. Int. J. Syst. Bacteriol. 41:582-587.

18. Hernandez-Lucas, I., L. Segovia, E. Martinez-Romero, and S. G. Pueppke. 1995. Phylogenetic relationships and host range of Rhizobium spp. that nodulate Phaseolus vulgaris L. Appl. Environ. Microbiol. 61:2775-2779.

19. Higgins, D. G., and P. M. Sharp. 1988. Clustal: a package for performing multiple alignment on a microcomputer. Gene 73:237-244.

20. Jarvis, B. D. W., H. L. Downer, and J. P. W. Young. 1992. Phylogeny of fast-growing soybean-nodulating rhizobia supports synonymy of Sinorhizobium and Rhizobium and assignment to Rhizobium fredii. Int. J. Syst. Bacteriol. 42:93-96.

21. Jarvis, B. D. W., T. S. MacLean, I. G. C. Robertson, and G. R. Fanning. 1977. Phenetic similarity and DNA base sequence homology of root nodule bacteria from New Zealand native legumes and Rhizobium strains from agricultural plants. N. Z. J. Agric. Res. 20:235-248.

22. Jarvis, B. D. W., C. E. Pankhurst, and J. J. Patel. 1982. Rhizobium loti, a new species of legume root nodule bacteria. Int. J. Syst. Bacteriol. 32:378-380.

23. Jordan, D. C. 1984. Family III. Rhizobiaceae, p. 234-242. In N. R. Krieg and J. G. Holt (ed.), Bergey's manual of systematic bacteriology, vol. 1. The Williams and Wilkins Co., Baltimore, Md.

24. Kimura, M. 1980. A simple method for estimating evolutionary rates of base substitutions through comparative studies of nucleotide sequences. J. Mol. Evol. 16:11-120.

25. Laguerre, G., M. R. Allard, F. Revoy, and N. Amarger. 1994. Rapid identification of rhizobia by restriction fragment length polymorphism analysis of PCR-amplified 16S rRNA genes. Appl. Environ. Microbiol. 60:56-63.

26. Laguerre, G., M. Bardin, and N. Amarger. 1993. Isolation from soil of symbiotic and nonsymbiotic Rhizobium leguminosarum by DNA hybridization. Can. J. Microbiol. 39:1142-1149.

27. Laguerre, G., M. P. Fernandez, V. Edel, P. Normand, and N. Amarger. 1993. Genomic heterogeneity among French Rhizobium strains isolated from Phaseolus vulgaris L. Int. J. Syst. Bacteriol. 43:761-767.

28. Laguerre, G., E. Geniaux, S. I. Mazurier, R. Rodriguez-Casartelli, and N. Amarger. 1993. Conformity and diversity among field isolates of $R$. leguminosarum bv. viciae, bv. trifolii, and bv. phaseoli revealed by DNA hybridization using chromosome and plasmid probes. Can. J. Microbiol. 39:412-419.

29. Laguerre, G., P. van Berkum, N. Amarger, and D. Prévost. Rhizobia isolated from Astragalus, Oxytropis and Onobrychis spp.: estimated phylogeny by analysis of mapped restriction site polymorphism (MRSP) within 16S rRNA genes and determination of genomic diversity by PCR DNA fingerprinting. Submitted for publication.

30. Lindström, K. 1989. Rhizobium galegae, a new species of legume root nodule bacteria. Int. J. Syst. Bacteriol. 39:365-367.

31. Lindström, K., P. van Berkum, M. Gillis, E. Martinez, N. Novikova, and B. Jarvis. 1995. Report from the roundtable on Rhizobium taxonomy, p. 807
810. In I. A. Tikhonovich, N. A. Provorov, V. I. Romanov, and W. E. Newton (ed.), Nitrogen fixation: fundamentals and applications. Kluwer, Dordrecht, The Netherlands.

32. Lortet, G., N. Méar, J. Lorquin, B. Dreyfus, P. de Lajudie, C. Rosenberg, and C. Boivin. 1996. Nod factor thin layer chromatography profiling as a tool to characterize symbiotic specificity of rhizobial strains: application to Sinorhizobium saheli, S. teranga, and Rhizobium sp. strains isolated from Acacia and Sesbania. Mol. Plant Microbe Interact. 9:736-747.

33. Martinez, E., M. Florès, S. Brom, D. Romero, G. Davila, and R. Palacios. 1988. Rhizobium phaseoli: a molecular genetics view. Plant Soil 108:179-184.

34. Martinez, E., R. Palacios, and F. Sanchez. 1987. Nitrogen-fixing nodules induced by Agrobacterium tumefaciens harboring Rhizobium phaseoli plasmids. J. Bacteriol. 169:2828-2834.

35. Martinez, E., M. A. Pardo, R. Palacios, and M. A. Cevallos. 1985. Reiteration of nitrogen fixation gene sequences and specificity to Rhizobium in nodulation and nitrogen fixation in Phaseolus vulgaris. J. Gen. Microbiol 131:1779-1786.

36. Martinez-Romero, E., L. Segovia, F. M. Mercante, A. A. Franco, P. Graham and M. A. Pardo. 1991. Rhizobium tropici, a novel species nodulating Phaseolus vulgaris L. beans and Leucaena sp. trees. Int. J. Syst. Bacteriol. 41:417426.

37. Oyaizu, H., S. Matsumoto, K. Minamisawa, and T. Gamou. 1993. Distribution of rhizobia in leguminous plants surveyed by phylogenetic identification. J. Gen. Appl. Microbiol. 39:339-354.

38. Pinero, D., E. Martinez, and R. K. Selander. 1988. Genetic diversity and relationships among isolates of Rhizobium leguminosarum biovar phaseoli. Appl. Environ. Microbiol. 54:2825-2832.

39. Quinto, C., H. de la Vega, M. Flores, L. Fernandez, T. Ballado, G. Soberon, and R. Palacios. 1982. Reiteration of nitrogen fixation gene sequences in Rhizobium phaseoli. Nature (London) 299:724-726.

40. Robert, F. M., and E. L. Schmidt. 1985. Somatic serogroups among 55 strains of Rhizobium phaseoli. Can. J. Microbiol. 35:519-523.

41. Roberts, G. P., W. T. Leps, L. E. Silver, and W. J. Brill. 1980. Use of two-dimensional polyacrylamide gel electrophoresis to identify and to classify Rhizobium strains. Appl. Environ. Microbiol. 39:414-422.

42. Saitou, N., and M. Nei. 1987. The neighbor-joining method: a new method for reconstructing phylogenetic trees. Mol. Biol. Evol. 4:406-425.

43. Sanger, F., S. Nicklen, and A. R. Coulson. 1977. DNA sequencing with chain-terminating inhibitors. Proc. Natl. Acad. Sci. USA 74:5463-5467.

44. Segovia, L., J. P. W. Young, and E. Martinez-Romero. 1993. Reclassification of American Rhizobium leguminosarum biovar phaseoli type I strains as Rhizobium etli sp. nov. Int. J. Syst. Bacteriol. 43:374-377.

45. Sneath, P. H. A., and R. R. Sokal. 1973. Numerical taxonomy. The principles and practice of numerical classification. W. H. Freeman \& Co., San Francisco, Calif.

46. Sokal, R. R., and C. D. Michener. 1958. A statistical method for evaluating systematic relationships. Univ. Kans. Sci. Bull. 38:1409-1438.

47. Stackebrandt, E., and B. M. Goebel. 1994. Taxonomic note: a place for DNA-DNA reassociation and 16S rRNA sequence analysis in the present species definition in bacteriology. Int. J. Syst. Bacteriol. 44:846-849.

48. Swofford, D. L. 1993. PAUP: phylogenetic analysis using parsimony, version 3-1.1. Illinois Natural History Survey, Champaign.

49. Tjahjoleksono, A. 1993. Caractérisation et diversité des souches de Rhizobium nodulant le haricot (Phaseolus vulgaris L.) cultivé en 3 sites tropicaux. Ph.D. thesis. Université de Lyon, Villeurbanne, France.

50. van Berkum, P., D. Beyene, and B. D. Eardly. 1996. Phylogenetic relationships among Rhizobium species nodulating the common bean (Phaseolus vulgaris L.). Int. J. Syst. Bacteriol. 46:240-244.

51. Vandamme, P., B. Pot, M. Gillis, P. De Vos, K. Kersters, and J. Swings. 1996. Polyphasic taxonomy, a consensus approach to bacterial systematics. Microbiol. Rev. 60:407-438.

52. Vasquez, M., A. Davalos, A. De Las Penas, F. Sanchez, and C. Quinto. 1991. Novel organization of the common nodulation genes in Rhizobium leguminosarum bv. phaseoli strains. J. Bacteriol. 173:1250-1258.

53. Vincent, J. M. 1970. A manual for the practical study of root-nodule bacteria. IBP handbook no. 15. Blackwell Scientific Publications, Oxford, United Kingdom.

54. Willems, A., and M. D. Collins. 1993. Phylogenetic analysis of rhizobia and agrobacteria based on 16S rRNA gene sequence. Int. J. Syst. Bacteriol. 43:305-313

55. Young, J. P. W., H. L. Downer, and B. D. Eardly. 1991. Phylogeny of the phototrophic Rhizobium strain BTAi1 by polymerase chain reaction sequencing of a 16S rRNA gene segment. J. Bacteriol. 173:2271-2277.

56. Young, J. P. W., and K. E. Haukka. 1996. Diversity and phylogeny of rhizobia. New Phytol. 133:87-94. 